\title{
PRAKTEK LARANGAN MONOPOLI DAN PERSAINGAN USAHA TIDAK SEHAT PADA BANK PEMERINTAH DALAM MEMBERIKAN FASILITAS SUBSIDI PERUMAHAN
}

\section{PROHIBITION OF MONOPOLISTIC PRACTICES AND UNFAIR COMPETITION IN STATE BANK IN PROVIDING HOUSING SUBSIDY FACILITY}

\author{
R. Putri Rangkuti, \\ T.N Syamsah, dan \\ Ahmad Yani
}

\author{
Program Studi Hukum, Sekolah Pascasarjana, \\ Universitas Djuanda Bogor. \\ Korespondensi : R. Putri Rangkuti, Telp. 082125220999 \\ e-mail : putri.rangkuti@unida.ac.id
}

Jurnal Living Law, Vol. 11, No. 2, 2019

hlm. 116130

\begin{abstract}
The purpose of this research is to know and analyze the implementation and solution in monopoly practice and unfair business competition at government bank in giving facility for housing subsidy. This research uses descriptive and analytical approach, which supported by library research in order to specify this research purpose to give description about monopolistic practice in banking business in Indonesia. The results indicate that in fact, the practice of monopoly restrictions and fraudulent business competition has not run optimally and there is a fundamental weakness in it Law No. 5/1999 that mainly related to the status of implementing agencies of this law, obstacles and barriers that exist in the practical situation is the lack in implementing Law no .5 / 1999 even assessed the existence of conspiracy among banks and businessmen or other banks. Therefore there needs to be more assertive and more organized controls related to the practice of monopoly prohibition and fraudulent business competition.
\end{abstract}

Keywords : Monopoly and Competition, Housing, Bank

\begin{abstract}
Abstrak : Tujuan penelitian ini adalah Untuk mengetahui dan menganalisa implementasi serta solusi dalam praktek monopoli dan persaingan usaha tidak sehat pada bank pemerintah dalam memberikan fasilitas subsidi perumahan. Penelitian ini bersifat deskriptif dan analitis yang didukung oleh studi kepustakaan karena secara spesifik penelitian ini bertujuan memberikan gambaran mengenai praktek monopoli pada dunia perbankan di Indonesia. Hasil penelitian ini menunjukkan bahwa sebenarnya prakteknya larangan monopoli dan persaingan usaha tidak sehat belum berjalan optimal dan terdapat kelemahan mendasar didalamnya UU No.5/1999 terutama terkait dengan status lembaga pelaksana undang-undang ini, maslah dan hambatan yang ada dilapangan adalah kurang berjalannya UU No.5/1999 bahkan dinilai adanya persekongkolan dikalangan bank dan pengusaha atau bank lainnya. oleh karenanya perlu adanya kontrol lebih tegas dan lebih terorganisir terkait praktek larangan monopoli dan persaingan usaha tidak sehat.
\end{abstract}

Kata Kunci : Monopoli dan Persaingan, Perumahan, Bank

\section{PENDAHULUAN}

Pembangunan ekonomi harus diarahkan kepada terwujudnya kesejahteraan rakyat berdasarkan Pancasila dan UUD 1945 yang menganut sistem ekonomi kerakyatan. Sampai saat ini kasus persaingan tidak sehat kerap ditemukan dan disidangkan KPPU dan menjadi perhatian besar dalam dunia usaha. Cukup banyak kasus-kasus monopoli pada berbagai sektor seperti halnya terjadi juga pada sektor perbankan, hal tersebut tentunya akan mempersulit 
indonesia dalam menajalani persaingan ekonomi secara global.

Terjadinya sebuah persaingan tentunya bukan hal yang buruk, Persaingan usaha merupakan hal yang wajar di dunia usaha dan hal tersbut selain dapat menguntungkan produsen/ pengusaha, persaingan usaha juga menguntungkan konsumen, masyarakat dan negara. hal sebaliknya jika persaingan usaha tersebut mulai memasuki ke dalam keadaan persaingan tidak sehat (unfair competition), dimana produsen/ pengusaha mulai menjatuhkan lawannya untuk keuntungan sendiri tanpa mengindahkan kerugian yang diderita pihak lain, dengan cara persaingan yang tidak jujur, melawan hukum, atau setidak-tidaknya perbuatan yang dilakukan pelaku usaha tersebut dapat menghambat persaingan usaha yang sehat. ${ }^{1}$

Dalam prakteknya persaingan usaha sangat terpengaruh oleh berbagai kebijakan pemerintah atau kebijakan publik. Seharusnya kebijakan publik tersebut dibuat dengan wawasan yang berpihak kepada masyarakat, baik kepada produsen maupun kepada konsumen, namun kenyataannya banyak kebijakan yang menyangkut sektor usaha yang diwarnai dengan berbagai kepentingan terselubung dari pihak tertentu, hal itu salah satunya disebabkan karena sistem birokrasi dan perekonomian di Indonesia sarat dengan sistem persengkongkolan yang tidak sehat, maka persaingan itu sendiri menjadi terdistorsi.

Dalam dunia perbankan persaingan tidak sehat cendrung jarang sekali terjadi, setiap bank mempunyai produk serta pelayanan yang diberikan semaksimal mungkin sehinga terjadi suatu persaingan yang sehat, tetapi disisilain ada pihak perbankan yang memonopoli salah satu produk perbankan bahkan monopoli teresebut di bolehkan dan dilindungi oleh hukum atau disebut juga monopoli by low.

\footnotetext{
${ }^{1}$ Rachmadi Usman, Hukum Acara Persaingan Usaha Indonesia, selanjutnya dissebut Rachmadi Usman II, (Jakarta: Sinar Grafika, 2013), hlm 88
}

Pada umumnya terdapat beberapa karakteristik dari kartel. Pertama, terdapat konspirasi antara beberapa pelaku usaha. Kedua, melakukan penetapan harga. Ketiga, agar penetapan harga dapat efektif, maka dilakukan pula alokasi konsumen atau produksi atau wilayah. Keempat, adanya perbedaan kepentingan diantara pelaku usaha misalnya karena perbedaan biaya. Oleh karena itu perlu adanya kompromi diantara anggota kartel misalnya dengan adanya kompensasi dari anggota kartel yang besar kepada mereka yang lebih kecil. $^{2}$

Praktek kartel dapat berjalan sukses apabila pelaku usaha yang terlibat di dalam perjanjian kartel tersebut haruslah mayoritas dari pelaku usaha yang berkecimpung di dalam pasar tersebut. Karena apabila hanya sebagian kecil saja pelaku usaha yang terlibat di dalam perjanjian kartel biasanya perjanjian kartel tidak akan efektif dalam mempengaruhi pasokan produk di pasar, karena kekurangan pasokan di dalam pasar akan ditutupi oleh pasokan dari pelaku usaha yang tidak terlibat di dalam perjanjian kartel. ${ }^{3}$

Persaingan di dunia perbankan juga sangat mempengaruhi perkembangan perekonomian banyak prodak-prodak perbankan menampilkan produk yang sama dengan bungkusan yang menarik artinya bahwa setiap bank mempunyai teknik dan strategi sendiri untuk merebut hati konsumennya.

Dalam praktek monopoli ada sebagaian perbankan yang hanya menjual satu produk saja yang dijadikan andalan untuk mengembangan banknya. Bagi negara berkembang seperti Indonesia, implementasi hukum persaingan usaha bukanlah pekerjaan yang mudah. Terlebih

\footnotetext{
${ }^{2}$ Andi Fahmi Lubis dkk, Hukum Persaingan Usaha dalam Teks dan Konteks, Deutsche Gesellschaft für Technische Zusammenarbeit (GTZ) GmbH, 2009, halaman 107

${ }^{3}$ Andi Fahmi Lubis dkk, Hukum Persaingan Usaha dalam Teks dan Konteks, Deutsche Gesellschaft für Technische Zusammenarbeit (GTZ) GmbH, 2009, halaman 107
} 
masih adanya anggapan dikalangan Negara berkembang yang mengatakan bahwa implementasi hukum persaingan usaha yang berlebihan dapat mengganggu aktifitas bisnis pelaku usaha, dan kurang menguntungkan bagi perusahaanperusahaan nasional, ditambah biaya yang dibutuhkan dalam proses investigasi dugaan praktek anti persaingan juga tidaklah murah. ${ }^{4}$

Monopoli yang dilakukan oleh sejumlah BUMN memang awalnya adalah untuk kepentingan rakyat banyak. Tapi adanya perkembangan yang terjadi menyebabkan permintaan yang tidak bisa lagi diimbangi oleh BUMN-BUMN yang malakukan monopoli, pada akhirnya mendorong pemerintah untuk melakukan privatisasi dengan mengundang partisipasi swasta. belajar dari pengalaman justru dalam kondisi apa pun, monopoli cenderung boros, tidak efisien, dan korup atau minimal perusahaan monopoli itu terus merasa mapan dan "sulit" meningkatkan pelayanannya.

Dalam hal penyelenggaraan Perbankan, tentu seharusnya perbankan menghindari praktik-pratik monopoli dalam pengembangan keuangan inklusif. Hal itu mengingat arah dasar program nasional keuangan inklusif adalah pemerataan ekonomi melalui akses layanan keuangan formal. Masyarakat yang belum terakses layanan keuangan formal harus menjadi prioritas, termasuk salah satunya dalam hal pembiayaan perumahan. ${ }^{5}$

Adanya program subsidi yang disediakan oleh pemerintah seperti fasilitas likuiditas pembiayaan perumahan, subsidi selisih bunga, dan subsidi uang muka yang

\footnotetext{
${ }^{4}$ Won-Joon Kim, “Korea's Experiences in Adoption \& Enforcement of Competition Law and Implication for Developing Countries," makalah disampaikan pada $2^{\text {nd }}$ ASEAN CONFERENCE ON COMPETITION LAW \& POLICY yang diselenggarakan oleh KPPU, Sekretariat ASEAN dan ASEAN Consultative Forum for Competition, di Bali pada tanggal 14-16 June 2006.

5 situs perumnas, diakses pada Senin, 26 Februari 2018 pukul 14.41. http://www.perumnas.co.id/holdingbumn-perumahan-diarahkan-jadi-penyedia-perumahan/
}

pada umumnya dikerjasamakan dengan bank harus dibuka tidak hanya pada bankbank pemerintah, tapi pada semua bank yang ada di Insonesia.

Persoalan lainnya adalah terkait usia dari Undang-undang No.5 Tahun 1999 tentang Larangan Praktek Monopoli dan Pesaingan Usaha Tidak Sehat (UU No.5 Tahun 1999) pada Tahun 2018 ini telah mencapai lebih dari delapan belas atau menginjak usia 19 tahun. Sehingga alangkah baiknya jika dilakukan suatu evaluasi terhadap bagaimana efektifitas dari penegakkan atau implementasi UU No.5 Tahun 1999, dan evaluasi tersebut bertujuan untuk melihat apakah implementasi UU No.5 Tahun 1999 selama ini telah sesuai dengan yang diharapkan ataukah masih belum sesuai dengan yang diharapkan.

Namun untuk melihat bagaimana efektifitas dari penyelenggaraan persaingan usaha terhadap berbagai sektor industri yang ada bukanlah tugas yang mudah dan juga tidak dapat dilakukan dalam jangka waktu yang relatif singkat, oleh karenanya berdasarkan latar belakang di atas judul dalam penulisan penelitian ini adalah Praktek Larangan Monopoli Dan Persaingan Usaha Tidak Sehat Pada Bank Pemerintah Dalam Memberikan Fasilitas Subsidi Perumahan.

Berdasarkan latar belakang sebagaimana di atas, maka dapat kami rumuskan identifikasi masalah sebagai berikut:

1. Bagaimana praktek larangan monopoli dan persaingan usaha tidak sehat pada bank pemerintah dalam memberikan fasilitas subsidi perumahan?

2. Bagaimana solusi agar tidak terjadi praktek monopoli dan persaingan usaha tidak sehat pada bank pemerintah dalam memberikan fasilitas subsidi perumahan?

\section{METODE PENELITIAN}

Metode penelitian yang digunakan peneliti adalah deskriptif dengan pendekatan kualitatif. Memusatkan 
perhatian terhadap masalah-masalah atau fenomena yang ada pada saat penelitian dilakukan atau bersifat aktual, kemudian menggambarkan fakta-fakta tentang masalah yang diselidiki sebagaimana adanya diiringi dengan interpretasi rasional yang akurat. Berdasarkan pemahaman di atas, maka penelitian ini menjelaskan fakta-fakta yang berhasil dikumpulkan terkait dengan objek penelitian untuk kemudian dianalisa kebenarannya sesuai dengan data yang berhasil didapatkan.

\section{PEMBAHASAN}

\section{A. PRAKTEK LARANGAN MONOPOLI DAN PERSAINGAN USAHA TIDAK SEHAT PADA BANK BTN CABANG KOTA BOGOR DALAM MEMBERIKAN FASILITAS SUBSIDI PERUMAHAN RAKYAT}

Secara sederhana dapat kami bahas bahwa penegakan hukum oleh KPPU terhadap larangan praktek monopoli dan persaingan usaha tidak sehat cukup lemah. begitu juga pada Bank Pemerintah dalam kajian ini adalah bank Tabungan Negara (BTN), hal tersebut salah satunya adalah karena kedudukan Komisi Pengawas Persaingan Usaha (KPPU) dalam sistem penegakan hukum Indonesia secara konseptual memiliki kelemahan yang cukup mendasar, mengingat tugas, wewenang dan tatacara penanganan perkara menumpuk di satu organ yaitu KPPU.

KPPU menjadi Penyelidik, Penyidik, Penuntut dan Pemutus Perkara (menjadi Hakim) sekaligus. Berdasarkan analisa konsepsional, menunjukkan kedudukan KPPU sesungguhnya dapat dikategorikan sebagai Badan Tata Usaha Negara, anggotanya sebagai Pejabat Tata Usaha Negara, sedangkan tugas dan wewenangnya merupakan tindakan hukum publik (administratif) dan bukan tindakan hukum perdata atau pidana.
Hal tersebut berpengaruh pula pada kekuatan mengikat suatu putusan. Kekuatan mengikat suatu putusan terletak pada diktumnya. Diktum ini hanya mengikat atau berlaku bagi para pihak atau terhukum saja, ini berarti para pihak atau terhukum harus mematuhi dan melaksanakan bunyi diktum tersebut. Diktum dalam putusan KPPU masih belum tegas, karena kedudukan KPPU secara konseptual masih belum jelas apakah sebagai lembaga peradilan ataukah lembaga/Badan Tata Usaha Negara. Hal tersebut berakibat pula pada penegakan hukum oleh KPPU sehubungan larangan praktek monopoli dan persaingan usaha tidak sehat. Lemahnya penegakan hukum ini disebabkan faktor hukumnya, aparat hukumnya, sarana/fasilitas untuk mengawasi perilaku pelaku usaha serta faktor budaya/masyarakat para pelaku usaha dan atau asosiasinya.

\section{Dalam}

penyelenggaraan perekonomian, persaingan harus dipandang sebagai hal yang positif. Pada Teori Ilmu Ekonomi sebuah persaingan yang sempurna merupakan suatu kondisi pasar yang ideal dan paling tidak terdapat empat asumsi yang menjadi dasar agar terjadinya persaingan yang sempurna pada suatu pasar tertentu: 6

1. Pelaku usaha tidak dapat menentukan secara sepihak harga atas produk atau jasa. Adapun yang menentukan harga adalah pasar berdasarkan equilibrium permintaan dan penawaran.

2. Kedua barang dan jasa yang dihasilkan oleh pelaku usaha mempunyai kebebasan untuk masuk ataupun keluar dari pasar "perfect homogeneity"

3. Ketiga pelaku usaha mempunyai kebebasan untuk masuk ataupun keluar dari pasar "perfect mobility of resource" dan Keempat konsumen dan pelaku pasar memiliki informasi yang sempurna tentang berbagai hal.

\footnotetext{
${ }^{6}$ Robert S Pindycle and Daniel L. Rubinfeld, Microeconomic, USA : Prentice Hall International Inc, 1998, Hal. 283-284.
} 
Walaupun dalam kehidupan nyata sukar ditemui pasar yang didasarkan pada mekanisme persaingan yang sempurna, namun persaingan dianggap sebagai suatu hal yang esensial dalam ekonomi pasar. Oleh karena dalam keadaan nyata yang kerap terjadi adalah persaingan tidak sempurna. Persaingan yang tidak sempurna terdiri dari persaingan monopolistik dan oligopoli. Persaingan memberikan keuntungan kepada para pelaku usaha maupun kepada konsumen.

Dengan adanya persaingan maka pelaku usaha akan berlomba-lomba untuk terus memperbaiki produk ataupun jasa yang dihasilkan sehingga pelaku usaha terus menerus melakukan inovasi dan berupaya keras memberi produk atau jasa yang terbaik bagi konsumen. Persaingan akan berdampak pada efisiensinya pelaku usaha dalam menghasilkan produk atau jasa.

Disisi lain dengan adanya persaingan maka konsumen sangat diuntungkan karena mereka mempunyai pilihan dalam membeli produk atau jasa tertentu dengan harga yang murah dan kualitas baik. Suatu pasar dimana tidak terdapat persaingan disebut sebagai "monopoli".

Ada beberapa asumsi yang menjadi dasar untuk menentukan adanya monopoli. ${ }^{7}$ Pertama, apabila pelaku usaha mempunyai pengaruh untuk menentukan harga. Kedua, pelaku usaha tidak merasa perlu untuk menyesuaikan diri terhadap pesaing dan terakhir, adanya "entry barrier" bagi pelaku usaha yang ingin masuk dalam pasar yang sudah dimonopoli oleh pelaku usaha. Setelah membaca asumsi-asumsi di atas, persaingan yang tidak sehat akan mematikan persaingan itu sendiri dan pada gilirannya akan memunculkan monopoli.

Membahas mengenai hukum persaingan yang merupakan salah satu bagian dari hukum ekonomi, tentu tidak akan lepas dari pembahasan dari mengenai

\footnotetext{
${ }^{7}$ Michael-Kantz dan Harveey S Rosen, "Microeconomic", USA : Richard D Irwin Inc, 1994, Hal. 432-433
}

Pasal 33 Undang-undang Dasar 1945 yang berfungsi sebagai panduan normatif dalam menyusun kebijakan-kebijakan ekonomi nasional.

Melalui Pasal 33 Undang-undang Dasar 1945 tersirat bahwa tujuan pembangunan ekonomi yang hendak dicapai haruslah berdasarkan kepada demokrasi yang bersifat kerakyatan yaitu adanya keadilan sosial bagi seluruh rakyat Indonesia. Undangundang Dasar 1945 melindungi kepentingan rakyat melalui pendekatan kesejahteraan dengan membiarkan mekanisme pasar berjalan dengan bebas, Pasal 33 Undang-undang Dasar 1945 juga memberikan petunjuk bahwa jalannya perekonomian nasional tidak diserahkan begitu saja kepada pasar, tetapi memerlukan peaturan perundangundangan untuk mengatur jalannya perekonomian nasional. Ayat 1 Pasal 33 Undang-undang Dasar 1945 mengandung arti bahwa perekonomian tidak dibiarkan tersusun sendiri atau terbentuk secara mandiri berdasarkan kekuatan-kekuatan ekonomi yang ada atau kekuatan pasar bebas. Ayat tersebut juga mengandung arti adanya upaya membangun secara struktural melalui tindakan nyata yang merupakan tugas negara. ${ }^{8}$

Pengaturan perekonomian dengan perundang-undangan tujuannya adalah untuk menciptakan struktur ekonomi nasional dalam rangka mewujudkan demokrasi ekonomi berdasarkan Pancasila dan Undang-undang Dasar 1945. Pengaturan tersebut untuk menghindari kemungkinan terjadinya hal-hal sebagai berikut :

1. Sistem free fight liberalism yang dapat menumbuhkan ekploitasi manusia dan bangsa lain, yang dalam sejarahnya di Indonesia telah menimbulkan kelemahan struktur ekonomi nasional

\footnotetext{
${ }^{8}$ Sri Edi Swasono, Demokrasi Ekonomi Keterkaitan Usaha Partisipatif Versus Konsentrasi Ekonomi, Makalah Seminar Pancasila sebagai Idiologi Negara dalam berbagai bidang kehidupan bermasyarakat berbangsa dan bernegara, Jakarta, 1989, Hal. 17.
} 
dalam posisi Indonesia dalam percaturan ekonomi dunia.

2. Sistem etatisme dalam arti bahwa negara berserta aparatur ekonomi negara bersifat dominan, mendesak dan mematikan potensi serta daya kreasi unit-unit ekonomi diluar sektor negara.

3. Persaingan tidak sehat serta pemusatan kekuatan ekonomi pada satu kelompok dalam berbagai bentuk monopoli dan monopsoni yang merugikan masyarakat dan bertentangan dengan cita-cita keadilan sosial. ${ }^{9}$

Dari isi GBHN mulai tahun 1973 sampai dengan tahun 1998, nampak bahwa GBHN selalu memberikan kesempatan pada pelaku usaha untuk tumbuh dan berkembang, bahkan sampai membentuk perusahaan raksasa yang dikenal dengan istilah konglomerat yang menjurus pada praktek monopoli. Praktek monopoli akan terjadi bila :

1. Monopoli diberikan kepada satu atau beberapa perusahaan tertentu saja, tanpa melalui Undang-undang.

2. Monopoli atau kedudukan monopolistik diperoleh dari kerjasama antara dua atau lebih organisasi sejenis baik dalam bentuk pengaturan persaingan diantara mereka sendiri maupun dalam bentuk peleburan atau fusi.

Menurut Kwik Kian Gie, kondisi tersebut diatas terjadi karena peran negara kepada suatu badan usaha, baik BUMN, usaha swasta maupun koperasi. ${ }^{10}$ Sedangkan Peter Mahmud Marzuki mengatakan bahwa monopoli yang dilarang oleh Undang-undang persaingan adalah monopoli yang menyebabkan terjadinya penentuan pasar, pembagian pasar dan konsentrasi pasar. ${ }^{11}$

\footnotetext{
${ }^{9}$ GBHN 1998, Butir G, Kaidah Penuntun (Surakarta, PT. Pabelan, 1998), Hal. 23.

${ }^{10}$ Kwik Kian Gie, Saya bermimpi jadi konglomerat (Jakarta, Gramedia, 1994, Hal. 233).

${ }^{11}$ Peter Mahmud Marzuki Telaah filosofi terhadap Undang-undang larangan praktek monopoli dam persaingan usaha tidak sehat dalam kaitannya dengan
}

Adanya konsentrasi pasar sebetulnya tidaklah selalu berakibat jelek bagi perekonomian, sepanjang industri tersebut dapat bekerja secara efisien dan tidak memanfaatkan konsentrasi yang tinggi untuk mengekploitasi konsumen dengan harga produk yang cukup mahal. Hal ini umumnya dapat terjadi apabila konsentrasi tersebut diperoleh melalui suatu proses persaingan alamiah, dengan kompetisi yang sehat telah melahirkan hanya satu atau beberapa perusahaan saja yang mendominasi pasar.

Apabila suatu pasar mempunyai produk tertentu dan hanya satu perusahaan yang ada dalam lingkup geografis yang menjual produk tersebut, dengan cara sedemikian rupa dapat menutup kemungkinan perusahaan lain untuk memproduksi dan menjual produk yang sama, maka perusahaan tersebut dapat dikatakan telah melakukan monopoli. Sebaliknya apabila perusahaan lain diberikan kesempatan yang sama untuk memproduksi barang tersebut, tetapi kesempatan itu tidak dipergunakan maka perusahaan tadi tidak dapat dikatakan melakukan monopoli. Namun demikian persoalan yang sering muncul adalah terjadinya suatu konsentrasi yang berebentuk monopoli/oligopoli karena berbagai perlindungan ataupun fasilitas birokrasi serta adanya kolusi bisnis yang mempersempit atau menghalangi masuknya pesaing-pesaing baru ke dalam pasar.

Disamping adanya akibat-akibat yang dapat menimbulkan kerugian pada konsumen karena tingginya harga, konsentrasi yang menekan munculnya persaingan banyak menimbulkan inefisiensi dalam perekonomian. Sebagai mata rantai adanya ketidakefisiennan tersebut, maka industri yang demikian membutuhkan proteksi terhadap pesaing dari luar dan sangat rendah kemampuan ekspornya. Hal ini dapat dilihat pada

konstitusi Republik Indonesia, (Majalah Yuridika, Surabaya, Fakultas Hukum Universitas Erlangga November 2001), Hal. 512. 
beberapa kelompok komoditi yang diproduksikan, dimana konsentrasi pasar dalam negerinya tinggi, kebanyakan orientasi kepasar ekspornya rendah. ${ }^{12}$

Dengan kondisi yang demikian dapat dibayangkan bahwa industri yang seperti itu akan sangat rentan dalam persaingan bebas, atau jika tidak ada proteksi dan fasilitas yang diberikan oleh pemerintah. Dengan tidak adanya perlindungan berupa proteksi, kuota dan sejenisnya, maka bukan saja sulit menembus pasar luar negeri namun juga akan sulit untuk mempertahankan pasar dalam negeri. Karena dengan adanya AFTA, WTO dan APEC, industri-industri kita nantinya harus siap bersaing dengan industri yang berasal dari negara lain, termasuk dari negara maju yang sudah sangat terbiasa dengan budaya persaingan bebas dan berproduksi secara efisien. ${ }^{13}$

Dengan gambaran tentang beberapa struktur industri di Indonesia, yang secara nyata memberikan ilustrasi adanya beberapa konsentrasi yang berimplikasi pada ketidakefisiennan. Konsentrasi industri yang demikian perlu dirombak, artinya jika konsentrasi itu muncul karena kebijakan pemerintah, maka kebijakan tersebut perlu dirubah dan diarahkan pada pembukaan peluang bagi pesaing baru untuk terjun pada sektor-sektor tersebut. Namun demikian jika hal itu terjadi karena adanya praktek-praktek kolusif ataupun kerja sama yang tidak fair, maka perlu dipikirkan pula sangsi yang tegas kepada para pelakunya. Jadi dibutuhkan perangkat hukum untuk mengambil tindakan berupa sangsi, misalnya terhadap praktek-praktek kartel terselubung atau praktek beberapa industri sejenis yang melakukan kolusi sehingga dapat mengendalikan pasar.

Tindakan tegas seperti ini sudah diterapkan di negara-negara kapitalis seperti USA, di Amerika Serikat ada Sherman Act yang usianya sudah lebih dari

\footnotetext{
${ }^{12}$ Edy Suandi Hamid, MB. Hendrie Anto, Ekonomi Indonesia Memasuki Milenium III, (Yogyakarta UII Pres, 2000), Hal. 50.

${ }^{13}$ Ibid, Hal. 51.
}

satu abad, isinya secara tegas melarang praktek kerja sama ataupun persengkokolan yang mengekang pedagangan, termasuk penetapan harga secara vertikal atau horisontal, pemboikotan bersama, pembagian pasar dan praktek-praktek dagang restriktif lainnya. Ketentuan seperti itu juga sudah sejak lama ada di negaranegara seperti Australia ataupun Eropa Barat. Perserikatan Bangsa-bangsa pun juga sudah mempunyai ketentuan sejenis, yakni Resolusi PBB no. 35.65 tahun 1967 yang dikenal dengan The Set Of Multilaterally Agreed Equitable Principles and Rules for the Control of Restrictive Business Practices. ${ }^{14}$

Namun demikian ditanah air kita hal ini masih menjadi perdebatan, karena aturan yang ada belum secara tegas mengatur aspek-aspek yang berkaitan dengan praktek monopoli, oligopoli dan praktek bisnis yang tidak jujur lainnya. Di negara tetangga kita, Thailand, perundangundangan mereka tentang anti monopoli sudah ada sejak tahun 1979, juga menegaskan larangan tantang kolusi bisnis, kesepakatan penetapan harga jual secara bersama, ataupun membagi-bagi dan mengalokasi wilayah distribusi produknya. Tingkat konsentrasi industri yang terjadi di Indonesia sudah terbilang cukup tinggi, di negara-negara industri seperti Inggris dan Amerika Serikat angkanya masing-masing $22 \%$ dan $36 \%$, sementara Indonesia sebesar $47,1 \% .15$

Ketidakberhasilan Pemerintah Orde Baru untuk menyetujui Undang-undang Antimonopoli, didasari beberapa alasan yaitu :

1. Pemerintah menganut konsep bahwa perusahaan-perusahaan besar perlu ditumbuhkan untuk menjadi lokomotif pembangunan. Perusahaanperusahaan

\footnotetext{
${ }^{14}$ Edy Suandi Hamid, Perekonomian Indonesia : Masalah dan Kebijakan Kontemporer, UII Press, Yogyakarta, 2000, Hal. 202.

${ }^{15}$ Iqbal, Farrukh, Deregulation and Development in Indonesia", Makalah Pada Seminar Building on Success : Maximizing the Gains From Deregulation, Jakarta, 1995, Hal. 17.
} 
tersebut hanya mungkin menjadi besar untuk kemudian menjalankan fungsinya sebagai lokomotif pembangunan apabila perusahaanperusahaan itu memberikan proteksi yang dapat menghalangi masuknya perusahaan lain dalam bidang usaha tersebut dengan kata lain memberikan posisi monopoli pada perusahaan tersebut.

2. Pemberian fasilitas monopoli perlu ditempuh karena perusahaan itu telah bersedia menjadi pioner disektor yang bersangkutan, tanpa fasilitas monopoli dan proteksi, maka sulit bagi pemerintah untuk dapat memperoleh kesediaan investor untuk menanamkan modalnya disektor tersebut. c. Untuk menjaga berlangsungnya praktek Korupsi, Kolusi dan Nepotisme demi kepentingan kroni-kroni mantan Presiden Soeharto dan pejabat-pejabat yang berkuasa pada waktu itu. ${ }^{16}$

Pasar dapat dikatakan dalam keadaan persaingan sempurna yaitu : bila terdapat banyak penjual dan pembeli kuantitas, barang-barang yang dijual oleh penjual dan dibeli oleh pembeli relatif kecil jumlahnya dibandingkan dengan kuantitas barangbarang yang tersedia pada suatu pasar, sehingga penjual tidak dapat mempengaruhi harga dari barang tersebut. Semua pembeli dan penjual memiliki informasi yang cukup mengenai hargaharga yang berlaku dipasar dan mengenai kualitas barang yang di jual, serta terdapat kebebasan perusahaan untuk masuk dan keluar dari pasar yang bersangkutan. ${ }^{17}$ Keuntungan yang besar merupakan salah satu tujuan dari monopoli, karena didalam monopoli selalu mengoptimalkan keuntungan "profit" dalam praktek persaingan, monopoli tidak selalu dilarang

\footnotetext{
${ }^{16}$ Sutan Remy Sjahdeni, Larangan Praktek Monopoli dan Persaingan Usaha Tidak Sehat, Makalah Diskusi Panel Tentang Antimonopoli, Diselenggarakan oleh Kelompok Kajian Ilmu Hukum Ekonomi Fakultas Hukum Universitas Padjajaran Bandung, Tanggal 4 September 1999.

${ }^{17}$ Moch Faisal Salam, Pertumbuhan Hukum Bisnis Di Indonesia, (Bandung, Pustaka, 2001), Hal.315
}

oleh Pemerintah, ada beberapa monopoli yang diperbolehkan antara lain :

1. Monopoli yang diberikan kepada penemu barang baru, seperti oktroi dan paten. Maksudnya untuk memberikan intensif bagi pemikir yang kreatif dan inovatif.

2. Monopoli yang diberikan oleh pemerintah kepada BUMN, lazimnya barang yang diproduksi dianggap menguasai hajat hidup orang banyak. Sebagai misal, PLN, Garuda, Telkom dan sebagainya.

3. Monopoli yang diberikan kepada perusahaan swasta dengan kredit pemerintah,

4. Monopoli dan kedudukan monopolistik yang diperoleh secara natural karena monopolis menang dalam persaingan yang dilakukan secara sehat. Dalam hal demikian memang tidak apa-apa, namun entrance (masuknya siapa saja kedalam investasi yang sama harus terbuka lebar-lebar).

5. Monopoli dan kedudukan monopolistik yang diperoleh secara natural karena investasinya terlalu besar sehingga hanya satu saja yang berani dan bisa merealisasikan invesastinya. Meskipun demikian, pemerintah tetap harus bersikap persuasif dan kondusif di dalam memecahkan monopoli.

6. Monopoli dan kedudukan monopolistik yang terjadi karena pembentukan kartel ofensif.

7. Monopoli dan kedudukan monopolistik yang terjadi karena pembentukan kartel yang defensif.

8. Monopoli yang diberikan kepada suatu organisasi dengan maksud untuk membentuk dana bagi yayasan, yang dananya lalu dipakai untuk tujuan tertentu, seperti, kegiatan sosial dan sebagainya. 18

Undang-undang no.5 tahun 1999 tentang larangan praktek monopoli dan

\footnotetext{
${ }^{18}$ Kwik Kian Gie, Analisa Ekonomi Politik Indonesia, Sekolah Tinggi Ilmu Ekonomi IBII dan Gramedia Pustaka Utama, Jakarta 1994, Hal. 243-244.
} 
persaingan usaha tidak sehat mempunyai maksud untuk mewujudkan iklim usaha yang sehat sehingga memberikan kepastian dan kesempatan usaha yang sama kepada semua pelaku usaha, baik usaha kecil, usaha menengah maupun usaha besar. Undang-undang ini mempunyai tiga jenis sanksi terhadap pelaku persaingan tidak sehat dan pelaku monopoli, yaitu : sanksi administrasi, sanksi pidana pokok dan sanksi pidana tambahan. ${ }^{19}$ Sanksi administrasi merupakan wewenang KPPU, sedangkan sanksi-sanksi lainnya merupakan wewenang hakim peradilan. Namun demikian masih diperlukan peraturan pelaksanaan lain yang merujuk pada Hukum Acara untuk digunakan dalam menindak lanjuti Undangundang no. 5 tahun 1999, hal ini guna menghindari pertentangan pendapat dan perbedaan penafsiran.

Studi kasus terkait dengan penegakan hukum dalam hal praktek monopoli dan persaingan usaha tidak sehat tidak kami temukan pada Bank Tabungan Negara, akan tetapi terjadi pada Bang Rakyat Indonesia dengan kronologis kasus: Pihak PT. Bank Rakyat Indonesia (selanjutnya disebut Terlapor I), PT. Asuransi Jiwa Bringin Jiwa Sejahtera (selanjutnya disebut Terlapor II) dan PT. Heksa Eka Life Insurance (selanjutnya disebut Terlapor III), ketiganya diduga menolak dan atau menghalangi perusahaan asuransi jiwa lain untuk melakukan kegiatan usaha yang sama pada pasar produk asuransi jiwa bagi debitur Kredit Kepemilikan Rumah (KPR) Terlapor I di seluruh wilayah Indonesia. Produk Kredit Pemilikan Rumah (KPR) adalah salah satu produk perbankan yang mempersyaratkan adanya asuransi jiwa. Perkara ini berawal dari inisiatif KPPU yang menemukan adanya pembatasan pilihan konsumen atau nasabah Terlapor I ketika mengajukan kreditnya. Dalam proses tersebut, nasabah tidak memiliki

\footnotetext{
${ }^{19}$ Asril Sitompul, Praktek Monopoli dan Persaingan Usaha Tidak Sehat, Tinjauan Terhadap Undang-undang No.5 Tahun 1999, (Bandung, Citra Aditya Bakti, 1999), Hal.. 95.
}

pilihan asuransi jiwa lain yang mereka inginkan, selain yang ditetapkan oleh Terlapor I.

Hal ini dapat diketahui dengan adanya perjanjian KPR BRI yang dibuat antara Terlapor I selaku pelaku usaha dengan debitur KPR Terlapor I selaku pihak lain. Perjanjian KPR BRI tersebut memuat persyaratan bahwa debitur KPR Terlapor I selaku pihak yang menerima barang tertentu berupa KPR BRI, diwajibkan membeli barang lain yaitu dengan membayar premi untuk asuransi jiwa yang hanya dari Terlapor II dan Terlapor III selaku pelaku usaha pemasok. Berdasarkan model aktivitas kerjasama yang dilakukan oleh Terlapor I bersama Terlapor II dan Terlapor III ini artinya Terlapor Imelakukan kegiatan bancassurance dengan model bisnis referensi. Pihak bank dapat melakukan referensi dalam rangka produk bank atau referensi tidak dalam rangka produk bank. Bentuk referensi dalam rangka produk bank biasanya bank akan mereferensikan atau merekomendasikan produk asuransi menjadi persyaratan untuk memperoleh suatu produk perbankan nasabah misalnya KPR, kredit kendaraan bermotor, kredit kepada pegawai atau pensiunan, yang disertai dengan asuransi. Tetapi jika tidak dalam rangka produk bank, bank mereferensikan produk asuransi yang tidak menjadi persyaratan untuk memperoleh suatu produk perbankan kepada nasabah. Model aktivitas referensi yang dilakukan oleh Terlapor I adalah jenis aktivitas referensi dalam rangka produk bank. Persyaratan produk asuransi itu dimaksudkan untuk kepentingan dan perlindungan kepada bank atas resiko terkait dengan produk yang diterbitkan atau jasa yang dilaksanakan oleh bank kepada nasabah.

Konsumen in cassu debitur KPR Terlapor I tidak memiliki pilihan lain selain menyetujui klausul asuransi jiwa yang ditawarkan dalam perjanjian KPR-nya, dikarenakan konsumen berada pada posisi tawar yang lemah. Selain itu dari hasil 
pemeriksaan KPPU diketahui bahwa pelaku usaha lain yang dapat masuk ke pasar bersangkutan telah berkurang dengan persyaratan terms and conditions yang tidak feasible dan memberatkan sehingga pihak perusahaan asuransi lain seperti Avrist, Realife, Bumiputera, dan Alianz yang telah mencoba mengajukan penawaran kerjasama dengan Terlapor I, mengalami kesulitan untuk dapat melakukan pemasaran produk asuransi jiwa mereka ke nasabah Terlapor I. Berdasarkan hasil pemeriksaan KPPU tersebut, Majelis Komisi memutuskan perkara itu dalam Putusan KPPU No. 05/KPPU/-I/2014 yang menyatakan bahwa ketiganya terbukti secara sah dan meyakinkan melanggar Undang-Undang Nomor 5 Tahun 1999 Pasal 15 Ayat (2) tentang perjanjian tertutup dan Pasal 19 huruf a tentang penguasaan pasar.

Dari kasus tersebut, Komisi Pengawas Persaingan Usaha (KPPU) memutuskan nasabah Bank Rakyat Indonesia (BRI) mulai kini bebas memilih asuransi jiwa, ketika mereka mengajukan kredit pemilikan rumah (KPR) di salah satu badan usaha milik negara (BUMN) itu. "Kalau dulu nasabah hanya dapat menggunakan produk asuransi yang telah ditentukan oleh BRI. Contoh, produk dari konsorsium PT Asuransi Jiwa Bringin Jiwa Sejahtera (Bringin) dan PT Heksa Eka Life Insurance (Heksa)," kata Kepala Bagian Hubungan Masyarakat Biro Hukum, Hubungan Masyarakat dan Kerja Sama KPPU Deswin Nur, melalui siaran pers, Kamis (13/11). Menurut dia, keputusan itu dikeluarkan setelah amar putusan KPPU pada 11 November 2014 di Jakarta atas kasus dugaan perjanjian tertutup dan hambatan masuk oleh BRI dan konsorsium asuransi tersebut.

Dalam putusan yang dibacakan hampir tiga jam tersebut, KPPU meminta pembatalan perjanjian oleh BRI memuat persyaratan kewajiban Debitur KPR untuk hanya menggunakan asuransi jiwa dari konsorsium Bringin dan Heksa. "Kami juga meminta agar BRI menghentikan kegiatan yang menghalangi perusahaan asuransi jiwa lainnya untuk melakukan kegiatan usaha yang sama pada pasar bersangkutan," ujarnya. Selain itu, jelas dia, Majelis Komisi KPPU yang menyidangkan kasus tersebut, juga menjatuhkan sanksi denda kepada BRI sebesar Rp25 miliar, Bringin dengan nominal Rp19 miliar, dan Heksa sebesar Rp13 miliar. Putusan itu berdasarkan kesimpulan KPPU yang menyatakan bahwa ketiga perusahaan tersebut melanggar pasal 15 (2) terkait tying-in (pembelian berikat) dan pasal 19 (a) terkait hambatan masuk pasar. KPPU juga menyarankan agar Otoritas Jasa Keuangan (OJK) untuk segera memberikan sanksi atas bank yang melanggar pelaksanaan Surat Edaran Bank Indonesia No. 12/35/DPNP tanggal 23 Desember 2010. Surat itu tentang Penerapan Manajemen Resiko pada Bank yang Melakukan Aktivitas Kerjasama Pemasaran dengan Perusahaan Asuransi.

Dari sekian banyak permasalahan yang muncul dalam penegakan UU No.5/1999, biang keladinya sepertinya dari UU No.5/1999 sendiri. Mungkin apabila UU No.5 Tahun 1999 mengatur secara eksplisit mengenai kedudukan KPPU (Komisi Pengawas Persaingan Usaha) dalam sistem hukum Indonesia (apakah merupakan lembaga judicial ataukah lembaga eksekutif/tata usaha negara?) sudah barang tentu tidak akan muncul polemik yang berkepanjangan seperti sekarang ini.

Tetapi harus realistis, bahwa untuk melakukan suatu revisi terhadap UU No.5/1999 tidak mungkin dapat dilakukan dalam waktu dekat, memperhatikan pekerjaan rumah DPR dan Pemerintah yang sudah begitu menumpuk yang juga menuntut untuk segera diselesaikan, di samping itu revisi terhadap UU No.5/1999 harus mengisi daftar waiting list antrian RUU maupun revisi UU, yang mungkin menurut DPR dan Pemerintah jauh lebih penting untuk didahulukan.

Sebagai jalan tengah dari permasalahan di atas yang masuk akal untuk dapat dilakukan saat ini adalah 
bagaimana undang-undang yang sudah ada ini, dengan segala kekurangan yang ada, dapat dilaksanakan secara baik, karena UU No.5/1999 mungkin jauh lebih memberikan harapan bagi terciptanya persaingan usaha yang sehat di Indonesia, dibandingkan tidak ada UU No.5/1999 sama sekali.

Namun tidak sepatutnya, jika di dalam UU No.5/1999 baik di dalam pertimbangan maupun di dalam ketentuan pasal-pasalnya tidak terdapat satu kalimatpun yang secara eksplisit menyatakan bahwa KPPU merupakan suatu lembaga peradilan, lantas sudah cukup menjadi dasar untuk menyebutkan KPPU sebagai lembaga eksekutif/tata usaha negara.

Usaha yang dilakukan untuk mencari tahu mengenai kedudukan KPPU tidak cukup hanya dengan melihat ketentuan eksplisitnya saja, yang menyebutkan secara langsung KPPU sebagai lembaga yudisial (kecuali mungkin bagi ahli-ahli hukum yang menganut aliran positivis sempit adalah sudah cukup).

Seharusnya tugas dan wewenang yang dimiliki oleh KPPU (Pasal 35 dan 36 UU No.5/1999) yang antara lain, menerima laporan, melakukan penyelidikan, menyimpulkan hasil penyelidikan atas dugaan terjadinya praktek monopoli dan persaingan usaha tidak sehat, memanggil saksi, meminta keterangan dari instansi pemerintahan, bahkan sampai menjatuhkan sanksi berupa tindakan administratif kepada pelaku usaha yang melanggar UU No.5/1999.

Dasar pembentukan KPPU (Pasal 30 ayat (1) UU No.5/1999), dimana KPPU dibentuk untuk mengawasi pelaksanaan undang-undang. Serta Pasal 30 ayat (2) UU No.5/1999, yang antara lain menyebutkan KPPU adalah suatu Lembaga independent yang terlepas dari pengaruh dan kekuasaan pemerintah serta pihak lain, seharusnya tidak dikesampingkan begitu saja, dalam menentukan kedudukan KPPU dalam sistem hukum Indonesia.

Tidak mampunya KPPU dalam mempertahankan putusan yang telah menghukum pelaku usaha yang terlibat dalam persekongkolan tender transaksi disvestasi Indomobil di PN (Pengadilan Negeri) bukan $100 \%$ kesalahan semata dari KPPU itu sendiri.

Walaupun KPPU telah mendapatkan bukti mengenai terjadinya persekongkolan tender dalam transaksi disvestasi Indomobil, namun Pasal 22 yang mengatur mengenai persekongkolan tender dalam UU No.5/1999 tidak dapat menjerat pihakpihak yang terlibat dalam persekongkolan tersebut.

Karena penjelasan Pasal 22 UU No.5/1999 -yang mendefenisikan tender sebagai tawaran mengajukan harga untuk memborong suatu pekerjaan, untuk mengadakan barang-barang atau menyediakan jasa- telah membatasi defenisi tender pada Pasal 22, kemudian berakibat terhadap tender penjualan saham (disvestasi) yang dilakukan oleh BPPN tidak dapat dikatagorikan sebagai tender yang telah dirumuskan dalam penjelasan Pasal 22 UU No.5/1999.

Jadi kegagalan KPPU dalam mempertahankan putusannya di PN, juga merupakan sumbangan dari UU No.5/1999 yang telah mempersempit defenisi tender. sehingga pihak-pihak yang terlibat dalam persekongkolan tender disvestasi Indomobil tidak dapat dihukum oleh UU No.5/1999.

Tetapi bukan berarti para pihak yang terlibat dalam persekongkolan dapat cuci tangan dan bernapas lega, terutama BPPN. Jika ternyata persekongkolan tersebut mendapatkan restu dari BPPN dan itu dapat dibuktikan oleh aparat Kejaksaan (karena sebelumnya Kejaksaan Agung juga pernah memanggil pejabat-pejabat BPPN guna diminta keterangannya disekitar proses disvestasi Indomobil), maka bukan lagi UU No.5/1999 yang akan berbicara tetapi UU No.31/1999 tentang Pemberantasan Tindak Pidana Korupsi yang sudah barang tentu sanksi hukumannya jauh lebih berat .

Dan kegagalan KPPU di PN ini seharusnya jangan membuat KPPU 
kehilangan kepercayaan diri dalam menegakan hukum Persaingan usaha di Indonesia dan segera melakukan introspeksi diri, karena bangsa Indonesia yang masih berharap banyak terhadap kiprah KPPU ke depan dalam menegakan hukum persaingan usaha di Indonesia dan membuat iklim berusaha di Indonesia menjadi lebih sehat dan kompetitif.

\section{B. PEMECAHAN MASALAH DALAM PRAKTEK LARANGAN MONOPOLI DAN PERSAINGAN USAHA TIDAK SEHAT PADA BANK BTN CABANG KOTA BOGOR DALAM MEMBERIKAN FASILITAS SUBSIDI PERUMAHAN RAKYAT}

Melihat kondisi saat ini dan disadari bahwa realistis untuk melakukan suatu revisi terhadap UU No.5/1999 tidak mungkin dapat dilakukan dalam waktu cepat, memperhatikan pekerjaan rumah DPR dan Pemerintah yang sudah begitu menumpuk yang juga menuntut untuk segera diselesaikan, di samping itu revisi terhadap UU No.5/1999 harus mengisi daftar waiting list antrian RUU maupun revisi UU, yang mungkin menurut DPR dan Pemerintah jauh lebih penting untuk didahulukan.

Sebagai jalan tengah dari permasalahan di atas yang masuk akal untuk dapat dilakukan saat ini adalah bagaimana undang-undang yang sudah ada ini, dengan segala kekurangan yang ada, dapat dilaksanakan secara baik, karena UU No.5/1999 mungkin jauh lebih memberikan harapan bagi terciptanya persaingan usaha yang sehat di Indonesia, dibandingkan tidak ada UU No.5/1999 sama sekali.

Namun tidak sepatutnya, jika di dalam UU No.5/1999 baik di dalam pertimbangan maupun di dalam ketentuan pasal-pasalnya tidak terdapat satu kalimatpun yang secara eksplisit menyatakan bahwa KPPU merupakan suatu lembaga peradilan, lantas sudah cukup menjadi dasar untuk menyebutkan KPPU sebagai lembaga eksekutif/tata usaha negara.

Usaha yang dilakukan untuk mencari tahu mengenai kedudukan KPPU tidak cukup hanya dengan melihat ketentuan eksplisitnya saja, yang menyebutkan secara langsung KPPU sebagai lembaga yudisial (kecuali mungkin bagi ahli-ahli hukum yang menganut aliran positivis sempit adalah sudah cukup).

Seharusnya tugas dan wewenang yang dimiliki oleh KPPU (Pasal 35 dan 36 UU No.5/1999) yang antara lain, menerima laporan, melakukan penyelidikan, menyimpulkan hasil penyelidikan atas dugaan terjadinya praktek monopoli dan persaingan usaha tidak sehat, memanggil saksi, meminta keterangan dari instansi pemerintahan, bahkan sampai menjatuhkan sanksi berupa tindakan administratif kepada pelaku usaha yang melanggar UU No.5/1999.

Dan dasar pembentukan KPPU (Pasal 30 ayat (1) UU No.5/1999), dimana KPPU dibentuk untuk mengawasi pelaksanaan undang-undang. Serta Pasal 30 ayat (2) UU No.5/1999, yang antara lain menyebutkan KPPU adalah suatu Lembaga independent yang terlepas dari pengaruh dan kekuasaan pemerintah serta pihak lain, seharusnya tidak dikesampingkan begitu saja, dalam menentukan kedudukan KPPU dalam sistem hukum Indonesia.

Terkait kasus yang melibatkan Bank BRI maka hal di atas bukan berarti para pihak yang terlibat dalam persekongkolan dapat cuci tangan dan bernapas lega, terutama BPPN. Jika ternyata persekongkolan tersebut mendapatkan restu dari BPPN dan itu dapat dibuktikan oleh aparat Kejaksaan (karena sebelumnya Kejaksaan Agung juga pernah memanggil pejabat-pejabat BPPN guna diminta keterangannya disekitar proses disvestasi Indomobil), maka bukan lagi UU No.5/1999 yang akan berbicara tetapi UU No.31/1999 tentang Pemberantasan Tindak Pidana Korupsi yang sudah barang tentu sanksi hukumannya jauh lebih berat . 
Dalam konteks implementasi praktek larangan monopoli dan persaingan usaha pada bank pemerintah dalam memberikan fasilitas subsidi perumahan kami menangkap beberapa fenomena dan fakta lapangan yang membutuhkan solusi pemecahan masalah diantaranya adalah praktek implementasi dari UU No.5/1999 belum berjalan dengan baik karena selain sistem yang di atur dalam dari undangundang itu sendiri yang kurang baik, praktek dilapangan terutama pada bankbank pemerintah masih kurang pengawasan yang terinterasi.

Maka, solusi penyelesaiannya adalah dengan optimalisasi UU No.5/1999, jika memang belum dapat diperbaiki karena keterbatasan waktu. pemerintah memang harus mendorong penyediaan fasilitas perumahan tersebut salah satunya dengan mengoptimalkan UU No.5/1999. Bila memang memungkinkan untuk dibuat aturan pemerintah yang lebih aplikatif dalam mengatur praktek larangan monopoli dan persaingan usaha tidak sehat.

\section{KESIMPULAN}

1. Praktek larangan monopoli dan persaingan usaha tidak sehat dinilai masih lemah. hal tersebut karena adanya masalah dan hambatan dalam praktek larangan monopoli dan persaingan usaha tidak sehat diantaranya adalah dari UU No.5/1999 sendiri yang tidak mengatur secara eksplisit mengenai kedudukan KPPU (Komisi Pengawas Persaingan Usaha) dalam sistem hukum Indonesia (apakah merupakan lembaga judicial ataukah lembaga eksekutif/tata usaha negara?). hal tersebut menimbulkan banyak persoalan

2. Solusi praktek monopoli dan persaingan usaha tidak sehat pada bank pemerintah memang sebaiknya adalah dengan menyempurnakan UU No.5/1999. akan tetapi jika hal tersbut belum dapat dilakukan, maka solusi pertama adalah dengan mengoptimalkan peraturan perundang-undangan yang ada atau dapat dibuat aturan pemerintah yang lebih aplikatif.

\section{SARAN}

1. Mengingat usian UU No.5/1999 sudah cukup tua dan dan terdapat kelemahan mendasar di dalamnya, maka perlu adanya wancana untuk menyempurnakan UU No.5/1999 dengan cara membuat undang-undang baru. Dalam proses menununggu penyempurnaan undang-undang UU No.5/1999, maka pemerintah sebaiknya mengoptimalkan UU No.5/1999 dengan mengeluarkan peraturan pemerintah yang dikaji dengan baik sehingga dapat meminimalisir kekurangan dari UU No.5/1999;

2. Perlu adanya kontrol lebih tegas dan lebih terorganisir dari pemerintah khususnya pada bank penyelenggaraan penyediaan fasilitas perumahan bersubsidi, karena dalam prakteknya larangan monopoli dan persaingan usaha tidak sehat tidak berjalan optimal dan tidak mendorong percepatan penyediaan perumahan.

\section{DAFTAR PUSTAKA}

Andi Fahmi Lubis dkk, Hukum Persaingan Usaha dalam Teks dan Konteks, Deutsche Gesellschaft für Technische Zusammenarbeit (GTZ) GmbH, 2009

Andi Fahmi Lubis dkk, Hukum Persaingan Usaha dalam Teks dan Konteks, Deutsche Gesellschaft für Technische Zusammenarbeit (GTZ) GmbH, 2009 
Asril Sitompul, Praktek Monopoli dan Persaingan Usaha Tidak Sehat, Tinjauan Terhadap Undang-undang No.5 Tahun 1999, (Bandung, Citra Aditya Bakti, 1999)

Edy Suandi Hamid, MB. Hendrie Anto, Ekonomi Indonesia Memasuki Milenium III, (Yogyakarta UII Pres, 2000)

Edy Suandi Hamid, Perekonomian Indonesia : Masalah dan Kebijakan Kontemporer, UII Press, Yogyakarta, 2000

GBHN 1998, Butir G, Kaidah Penuntun (Surakarta, PT. Pabelan, 1998)

Iqbal, Farrukh, Deregulation and Development in Indonesia", Makalah Pada Seminar Building on Success : Maximizing the Gains From Deregulation, Jakarta, 1995

Kwik Kian Gie, Analisa Ekonomi Politik Indonesia, Sekolah Tinggi Ilmu Ekonomi IBII dan Gramedia Pustaka Utama, Jakarta 1994.

Kwik Kian Gie, Saya bermimpi jadi konglomerat (Jakarta, Gramedia, 1994)

Michael-Kantz dan Harveey S Rosen, "Microeconomic”, USA : Richard D Irwin Inc, 1994

Moch Faisal Salam, Pertumbuhan Hukum Bisnis Di Indonesia, (Bandung, Pustaka, 2001)

Peter Mahmud Marzuki Telaah filosofi terhadap Undang-undang larangan praktek monopoli dam persaingan usaha tidak sehat dalam kaitannya dengan konstitusi Republik Indonesia, (Majalah Yuridika, Surabaya, Fakultas Hukum Universitas Erlangga November 2001)

Rachmadi Usman, Hukum Acara Persaingan Usaha Indonesia, selanjutnya dissebut Rachmadi Usman II, (Jakarta: Sinar Grafika, 2013)

Robert S Pindycle and Daniel L. Rubinfeld, Microeconomic, USA : Prentice Hall International Inc, 1998

Sri Edi Swasono, Demokrasi Ekonomi Keterkaitan Usaha Partisipatif Versus Konsentrasi Ekonomi, Makalah Seminar Pancasila sebagai Idiologi Negara dalam berbagai bidang kehidupan bermasyarakat berbangsa dan bernegara, Jakarta, 1989

Sutan Remy Sjahdeni, Larangan Praktek Monopoli dan Persaingan Usaha Tidak Sehat, Makalah Diskusi Panel Tentang Antimonopoli, Diselenggarakan oleh Kelompok Kajian Ilmu Hukum Ekonomi Fakultas Hukum Universitas Padjajaran Bandung, Tanggal 4 September 1999.

Won-Joon Kim, “Korea's Experiences in Adoption \& Enforcement of Competition Law and Implication for Developing Countries," makalah disampaikan pada $2^{\text {nd }}$ ASEAN CONFERENCE ON COMPETITION LAW \& POLICY yang diselenggarakan oleh KPPU, Sekretariat ASEAN dan ASEAN Consultative Forum for Competition, di Bali pada tanggal 14-16 June 2006. 
situs perumnas, diakses pada Senin, 26 Februari 2018 pukul 14.41.

http://www.perumnas.co.id/holding-bumn-perumahan-diarahkan-jadi-penyediaperumahan/ 